\title{
A Comparative Analysis on Efficiency of the Student Loan Repayment Policy in Ghana, Kenya, Tanzania, Rwanda and Nigeria
}

\author{
Korankye Benjamin ${ }^{1}$, Xuezhou Wen ${ }^{1}$, Easmond Baah Nketia ${ }^{2}$ Godson Kweitsu $^{3}$ \\ ${ }^{1,2}$ School of Management and Economics (Jiangsu University), School of Finance and Economics (Jiangsu \\ University) \\ ${ }^{3}$ School of Public Affairs and Administration (University of Electronic Science and Technology of China)
}

\begin{abstract}
The Ghanaian student loan has been touted as an innovative policy to enhance human development yet the policy is contending with inherent inefficiencies. With the general objective of this study, to critically analyze the success and sustainability of the SLTF loan in Ghana through the repayment and recovery rate using the relative efficiency index (REI=Repayment Ratio / Recovery Ratio) as compare to other Africa countries. This research analyzed the repayment mechanism used in the Ghanaian SLTF and the other countries under study, focusing on a payment schedule, time-frame and the interest rate applied. From the research, although the repayment ratio is high mean, the value of loan amount is also high this suggests that there are gaps to be filled in terms of repayment. Loan repayment is also affected by the interest rate and the salary as shown in the data. The researcher recommends that the loan amount should be reviewed upwards while the repayment period of the student loan remains 10years. With trending issues based on others literature on student loans, the researcher can predict that the loan efficiency would be positive if a high percentage of the loans are paid by student borrowers within the repayment period.
\end{abstract}

Keywords: Efficiency, Student loans, Interest rate, Repayment rate, Default rate, the Recovery rate

\section{Introduction}

Funding for tertiary education all over the world is a crucial challenge for governments, policymakers, and university administrators. In developed countries, while governments provide some resources to finance higher education, there is a continuous effort on the part of university administrators to mobilize and diversify resources to supplement what governments provide. In the most advanced countries, there has been an upsurge in the demand for policy restructuring to reduce the overreliance on the federal and central governments in financing higher education. At the same time, there has been a gradual shift from the provision of free higher education in countries to a system of cost sharing where students contribute towards their education (Atuahene, 2008). However, the situation is quite different, mostly, between the rich and the poor, making higher education the preserve of the more affluent segments of society. In Africa countries, the introduction of cost sharing has generated serious inequalities. Students' loan programs now exist in many developed and developing countries.

Mostly student loan programs are financed from public funds or backed by government guarantees and these were found in countries like the U.S.A, Scandinavia, and Japan between the 1940s and 1950s (Woodhall, 2007). With this initiative, other developed countries set up a loan scheme in the 1960s including Canada and several European countries. Colombia was the first developing country to establish a student loan programmed, where the Instituto Colombiano de Credito Educativo Estudios Technicas en el Exterior (ICETEX) was established in 1953 and it was followed by many other student loan programs in Latin America in the 1950s and 1960s, (Agostino, 2008). By early 1980s student loan programs were established in Europe, North America, Latin America, the Caribbean, and few isolated examples in Asia and Africa of which Ghana was included. A review of the international experience of student loan programs found official loan programs that are run by government agencies or backed by government guarantees in more than thirty countries, (Agostino, 2008).

The loan has recently been proposed in several other 
countries, including the U.K., and New Zealand among developed countries, and Tanzania, South Africa, Kenya, Uganda among the developing countries. It has, therefore, become necessary imperative for the government to

Increase the loan intake from almost 1500 Ghana cedi to 3000 Ghana cedi per year from 2016 to 2018 (Graphic.com.gh, 2018). This shows an increase of almost $100 \%$ since costs are mostly indirectly shifted to students. Student Loans have helped parents to solve some of the educational problems in financing their wards.

In light of these challenges, the student loan has become the best alternative source of funding in some Africa countries like Ghana, Kenya, Rwanda, Tanzania, and Nigeria, in financing higher education. In a newspaper report dated 5th of November, 2015, thousands of Ghanaian students took to the street to protest against the government trying to take away part of some courses, been subsidized by the loan describing it 'irrelevant' not to have access to the loan again (Ghana web,

2015/11) Whiles in China, according to government data, Chinese authorities issued 103.2 billion Yuan (16.66 billion U.S. dollars) worth of student loans by the end of 2013, benefiting about 10 million students across the country. The Chinese government is implementing incentive measures to encourage commercial banks to provide loans to needy students who cannot otherwise afford higher education (CRI September 1, 2014). Student loan implementation has become a problem for Ghana governments since the inception of the Scheme in January 1989 under the Provisional National Defense Council (PNDC) Law 276 (Atuahene, 2008). However, Student Loan Trust Fund (SLTF) was introduced in December 2005 under the Trustees Incorporation Act 106 of 1962.

The legislation has since been replaced by the SLTF Act 820 of 2011 to release the burden of the student loan scheme system. The Students' Loan Scheme is a financial arrangement under which Ghanaian Students enrolled and pursuing approved courses in tertiary institutions in Ghana are granted loans to assist in financing their education likewise other African countries. With empirical evidence, the government of Ghana in 2001 owed the trust \$23.9 million, wanted part of the interest it had agreed to subsidize on students' loans (Rossouw, 2008) ' In line with is, as reported in the news on 22nd of June 2016, The Students Loan Trust Fund (STLF) has published the names of 31,223 persons who took student loans from it but have defaulted in paying back. Some of the names published on its website are said to have defaulted for close to ten years (Graphic.com.gh, 2018).

According to (Johnstone \& Marcucci, 2007) if students do not have to pay for their education they tend to consume education with insufficient academic effort since too little is forgone by the students. However, to-date, government-sponsored student loan schemes are already in place in over 70 countries of the world with one common feature: they are all highly subsidized by governments; and unlike commercial loans, a sizeable proportion of the total loans outlay by the loans body is often not received back in repayment (Shen \& Ziderman, 2009). The general objective of this study is to critically analyze the success and sustainability of the SLTF loan in Ghana through the repayment and recovery rate using the relative efficiency index as compared to other Africa countries. The study would be based on a systematic and independent assessment of the opinions of people and stakeholders about implementation, and achievement of the student loan policy.

\subsection{Repayment pattern of the student loan policy}

(Junor \& Usher, 2008) show in a Canadian context, even with steady levels of debt, changes in interest rates can change monthly repayment burdens by as much as 20 percent in just 3 years. Several conditions account for the repayment pattern of the student loan. The Students Loan Trust Fund (SLTF) in Ghana uses two different types of repayment pattern to get their loans back from their customers. Employer's notice and borrowers notice are two types of pattern that they used. With the employers' notice, the SLTF brings to the attention of all employers in both the private and public sectors that section 24 of the Students Loan Trust Fund Act, 2011 act 820. This ACT enjoins employers to ascertain from employees who are beneficiaries of student loans about their status and report those who have not fully repaid their loans to the SLTF. Employers are further mandated to withhold monthly installments from the salary of employees and remit same to the SLTF within fifteen (15) days after deduction. All employers are to note that failure to deduct and remit the same to the SLTF constitutes an offense under section 37 of the SLTF Act (Graphic.com.gh, 2018).

Whiles, with the borrowers' notice, the Students Loan Trust Fund (SLTF) notifies all borrowers of the fund that loan repayment can be made at any six banks branches across the country and fourteen (14) zonal offices across the country to make due the 
necessary payment. All employers are to note the provisions of the law and act accordingly to help sustain the scheme. However, the researcher has segmented the repayment pattern of the student loan into two, which the study would examine how they affect the payment positively or negatively.

\subsection{Student Loan Policy in Africa}

Under this section of the study, the researcher would review some of the policy of the under student loan and history of it in some Africa countries like Kenya, Rwanda, Tanzania, and Nigeria.

\subsubsection{History of the student loan policy in Kenya}

The Higher Education Loans Board (HELB), is the leading financier of higher education in Kenya. It is a State Corporation under the then Ministry of Higher Education, Science and Technology. HELB was established by an Act of Parliament (Cap 213A) in 1995(Graphic.com.gh, 2018). The mandate of the Board is to disburse loans, bursaries, and scholarship to students pursuing higher with a number of problems right on the onset. It lacked the legal basis to recover matured loans from loaners. In addition, the general public and university students wrongly perceived that the loan was a grant from the government, which was not to be repaid.

The origin of the Higher Education Loans Board dates back to 1952 when the then colonial government awarded loans under the then Higher Education Loans Fund (HELF) to Kenyans pursuing a university education in universities outside East Africa notably Britain, USA, former USSR, India, and South Africa. Students who were pursuing a university education in universities outside East Africa and were not on scholarships were advanced loans by the then government against securities such as Land Title Deeds, Insurance policies and Written Guarantees. The HELB doubling of new students had left the agency with no option other than to cut the maximum annual allocation per student to US\$555 from the current US\$666. This is a big knock to thousands of first-year students. However, the minimum allocation remained unchanged at US\$380 University financing crisis as student loans shrink (Simkovic, 2013).

In deducting a loanee, the monthly installments should not exceed $25 \%$ of a loanee basic pay. Loans to salaried students are expected to be repaid within 48 months upon disbursement. The establishment of a revolving fund was also expected to ease pressure on the exchequer in financing education, which currently stands at $40 \%$ of the annual national budget. The HELB disburses loans in three categories loan to direct entry students, loans to salaried students and Students pursuing Diploma and Certificate courses in Public universities, university colleges, public national polytechnics and Institutes of Technology and Technical Training institutes country-wide are eligible for this loan and bursary (TVET Loans) (http://www.helb.co.ke). The loans agency has targeted raising the student financing budget four-fold from the current US $\$ 63.5$ million to US\$224.7 million in 2018. (Simkovic, 2013)

\subsubsection{History of the student loan policy in Rwanda}

Law No 44/2010 of 07/12/2010 establishing Rwanda Education Board (REB) and determining its mission, organization, and functioning. It also determines its responsibilities, organization, and functioning. This Law establishes Rwanda Education Board abbreviated as "REB" in the official gazette No 4bis of 24/01/2011.

All those institutions were under the Ministry of Education before combination: National Examination Council (RNC), National Curriculum Development Center (NCDC), Student Financial Agency Rwanda (SFAR), General Inspection of Education (GIE), and Teacher Service Commission (TSC), all those institutions were combined and take the name of Rwanda Education Board (REB). After combining all those institutions REB contains 6 Departments. (REB Constitution)

According to a news report on Rwanda student loans, 66,750 people have benefited from the student loan scheme since 1980, in addition to the 18,274 current students in all branches of University of Rwanda, according to HESLB records.

Only 50,533 students have graduated and 11,000 started to repay their loans, leaving the other 41,819 untraceable or refusing to pay back. (Rwanda, 2014) However, this shows the default rate and problems entangling most of the student loans scheme in Africa.

Ms. Karamage, however, said at least Rwf6.7 billion had been collected, with many government officials clearing their loans (Rwanda, 2014)

\subsubsection{History of the student loan policy in Tanzania}

The Higher Education Student Loan Scheme (HESLS) was introduced in Tanzania in 1994 to encourage cost-sharing in higher education (Nyahende, 2017). Since1994 when the HESLS introduced, the loans were advanced by the Government through the then Ministry of Higher 
Education, Science, and Technology (MHEST). At that particular time, the government made a number of changes/reforms in a bid to improve policy implementation and management of students 'loan scheme. However, the biggest ever reform took place in 2004 with the enactment of Act No 9 of 2004 (CAP178) as amended and the subsequent establishment of Higher Education Students' Loan Board (HESLB).

HESLB started its operation in July 2005 and since then the loans are advanced by the government through HESLB (HESLB strategic planning 2008 2011). HESLB was set up to provide financial facilitation in terms of loans to eligible and needy students to help them to pay for their education (HESLB Act, 2004). Apart from increasing efficiency in disbursing and collecting loans, HESLB is also assigned two primary tasks.

Initially, the Board allocated loans to students manually due to lack of a computerized system which could carry out means testing for the loan applicants. This forced the Board to issue $100 \%$ loans to all applicants in 2005/2006. However, with the assistance of the Government, HESLB purchased and installed a Loan Management System in 2006/2007; which was subsequently improved in 2007/2008 making it able to carry out means-testing for loan applicants. Therefore, beginning July 2007 loans were given to students based on their economic abilities. (Mussa, 2015)

\subsubsection{History of the student loan policy in Nigeria}

The Nigerian Students Loans Board was initially settled in 1972, and in the vicinity of 1973 and 1991, it gave advances totaling 46 million Naira to help Nigerian students undergraduate or postgraduate programs back in Nigeria or abroad (Secretary, Students, \& Board, 1992). A bill to make a research credit conspire called a Higher Education Board has passed a moment examining in the country and this is required to be affirmed soon. Mostly, loans are taken with a processing fee of Nigeria Naira (NGN) NGN2000 without interest and loans are paid one to two years after completion. Not surprisingly, there was a celebration among understudies over the plan, which is remarkable in Nigerian advanced education. The Loan to undergraduate is calculated to replace an expected debt burden ranging from NGN 24,000 NGN 32,000(Board, 2018)

To fit the bill for a loan, the student must originate from a home with a yearly salary of under US $\$ 3,165$ a year. He or she should likewise have secured admission to any college, polytechnic, and school of instruction or professional organization set up by the elected or a state government. Repayment of advances will start two years after understudies have finished necessary National Youth Service Corps benefit. Reimbursement will be in portions as the immediate reasoning of $10 \%$ of a utilized research's compensation at the source, deducted by the business and credited to the research's advance in the instruction bank. For independently employed graduates, a statement in the bill makes it required for recipients to dispatch $10 \%$ of their aggregate month to month benefit to the bank. The bill cautions that defaulting loan recipients will be prosecuted, and if discovered liable will confront jail sentences of up to two years or a fine of US\$3,165, to be paid in nearby cash. (Fatunde, 2013)

\subsection{Income Contingent Repayment (ICR)}

With this type of payment, the arrangement is mostly used for student borrowers of a new graduate, where his or her ability to pay the loan is limited by his or her income.

There are two main types of income-contingent loans, these are income contingent with risk pooling and income contingent with risk-sharing. The first form of income contingent loans is income contingent with risk pooling. According to (Ziderman, 2013) (Woodhall, 2007), this type of an income contingent loan is a system where a cohort of students signing up on the debt repayment, is also agreeing to take the responsibility of paying the debt of students who are unable to do so. This kind of loans acts as an insurance against default and nonrepayment since the loan will be shared among the graduates.

Whiles, the income contingent with risk-sharing differs from the income contingency with riskpooling in the sense that the repayments in the risksharing, the IRLs do not depend on the income or payment of other borrowers. The quantity of income contingency is shared with the taxpayers or the government and not with other borrowers (Chapman \& Lorraine, 2017).

Instead, students are simply permitted to abstain from payment until such time as their income recovers, and the cost of this "payment holiday" is absorbed up in the more general interest subsidies (Shen \& Ziderman, 2009).

In Canada, this is known as "interest relief', New Zealand as a "Base Interest Write- Off" or "Base Interest Reduction" (the former is a full subsidy, the latter a partial one), and in the Netherlands, Germany, and United States as "deferment." In the Netherlands and Germany, these deferrals do not cost the government any extra money; in the 
Netherlands because the interest is recapitalized into the loan and in Germany because the cost is already subsumed by the general zero-interest cost (technically, there is a cost because it extends the life of the loan, but this is difficult to calculate) (Shen \& Ziderman, 2009). With the Ghanaian scheme, the borrowers' notice shows the Students Loan Trust Fund (SLTF) notifies all borrowers of the fund that, loan repayment can be made at any six (6) banks branches across the country and fourteen (14) zonal offices across the country to make due the necessary payment (gov.sltf.com).

If your calculated payment amount is not sufficient to satisfy the interest that accrues (adds up) during your repayment period, the outstanding interest will be capitalized (added to your loan balance) annually. The capitalized interest cannot exceed $10 \%$ of your total original loan balance. Once this maximum amount is reached, interest will continue to accrue but will no longer be capitalized.

\section{Related Work}

Within the student loan default fiction, there are three primary frameworks that are used to describe the usage of student loans as a financing tool for paying for higher education. These frameworks include the human capital theory, ability to pay, and social integration model (Kypuros; Christopher Anthony, 2009).

\subsection{The human capital theory}

Generally, the human capital theory is used to explain that students are willing to borrow to pay for their education based on the expectation that their investment will bring future financial returns (Flint, 1997). The question is who should bear these costs? Higher education benefits the individual and society as well. The private benefits are a justification why the individual and their families should bear the cost of higher education (Marcucci \& Johnstone, 2006). This theory addresses and incorporates pre-college factors that relate to a student's retention and willingness to graduate. The earnings of a person with higher education do not show the external benefits that affect society as a whole (Psacharopoulos \& Patrinos, 2004). Hence investing in human capital benefits the whole society in the improvement and transformation process, the spillover effect that has on the society is a rationalization why the government (including the taxpayers) should subsidize higher education (Pantah, 2018).

\subsection{The ability to pay theory}

The ability to pay theory rationalizes both the government's intent to subsidize students who are academically ambitious but have the least available income and most limited safety net (Flint, 1997). To emphasize the work of flints, it means to pursue high education, one needs to provide evidence in terms of guarantors' security, job opportunity, etc. if these are highly available to secure the authenticity of the student loaner and to have access to the loan, he or she would be assured of given the required amount to pursue his or her higher education.

\subsection{The social integration models}

Lastly, the social integration model helps explain how environmental determinants during both college and post-college can influence ones' behavior (Flint, 1997). The environment in college and post-college may include low performance in exams, political unrest, economic recession, inflation, unemployment, misappropriation of funds by the governments, and many others. This model helps both partners to plan well in whatever decision they take. Building upon these basic frameworks and taking into account the many factors known for having effects on individual student loan defaults, such as family demographics, college experiences and institutional characteristics, and post-college experiences and economic factors, the basis for my conceptual framework departs from the linear framework typically applied to determine student loan defaults.

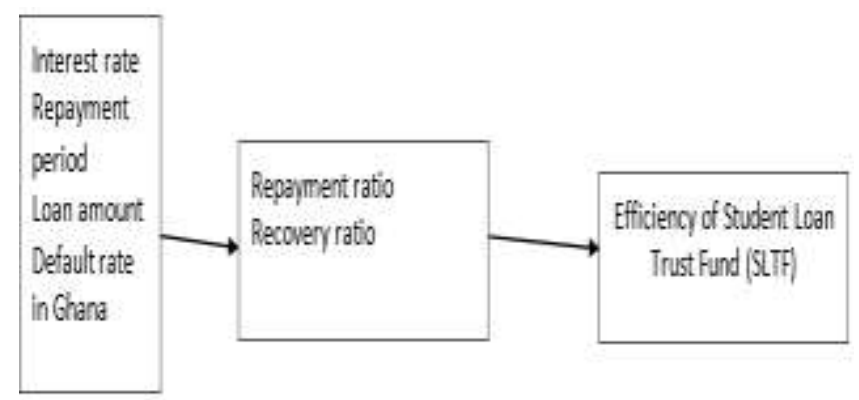

Source: Author elaboration (2017)

Figure 1 the conceptual frameworks of the factors that underlie an individual's likelihood of default Instead of approaching defaults from a linear effect of interest rate, repayment period, loan amount, I believe that there is greater inter-connectivity between the efficiency of the students' loan trust fund with the repayment ratio and recovery ratio serving as a causative agent.

\section{Methods}

This chapter presents the methods used in collecting data for the study. It deals with the theoretical framework of the student loan repayment policy, the research model, data collection tools, data analysis 
tools; a discussion is based on the independent and dependent variable. The current version of Excel and SPSS was used in the computation and drawing of graphs for this study data from the various website of the countries under study. Data was retrieve from the various website of the study for 2016 .

\subsection{Factors that affect the efficiency of the student loan policy}

The underlining principle is that according to (Woodhall, 2007) for example observed that arguments in favor of repayable loans are based on both efficiency and equity. With the relevant of the loan to the student factors that affect the interest rate, repayment period, loan amount, default rate in Ghana would the determine how efficient the SLTF would stand if, the recovery ratio is less than the repayment ratio. Here the underlying concepts that influence loan default are relatively complex and circular.

Building upon the definition individual loan default, the cohort default rate metric is an aggregate of individuals defaulting in any given student cohort. For the purpose of my study in isolating economic effects on the institutional cohort default rate, I expand my basic conceptual model.

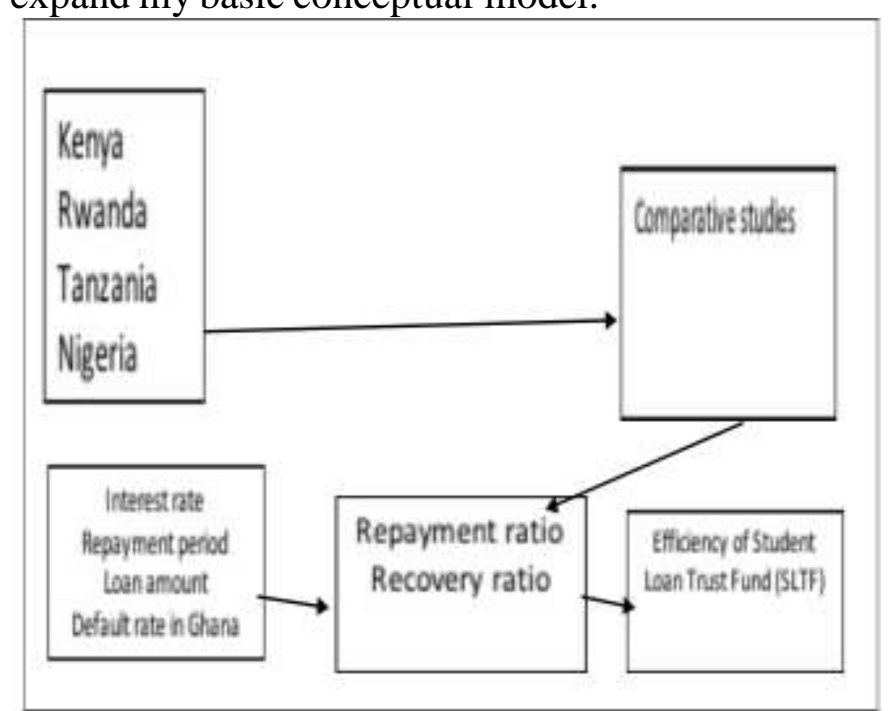

Source: Author Elaboration (2017)

Figure 2: This expansion assumes that the underlying individual determinants are fixed amongst a cohort at each particular institution.

With the same system apply to some other African countries like Kenya, Rwanda, Tanzania and Nigeria comparative studies would be made in their repayment ratio and recovery ratio. In other to determine how efficient the various loans scheme in this country is, according to Shen (2009) one need to compete for relative efficiency index (REI)

\section{Relative Efficiency Index (REI) = Repayment}

\section{Ratio / Recovery Ratio}

To define the REI, one needs to know the Repayment ratio, this measures how much a loan an average borrower is required to repay: it is defined as the ratio of required repayments to the loan size received, both measured in terms of present values. Government-sponsored loans scheme is "softer" than those of commercial loans when it's come to lending. Once this identifies, the difference left shows the subsidy student received, which the borrower is not required to pay back the full value of the loan received. To understand the recovery ratio; one needs to know that, the repayment ratio relates to the typical borrower, therefore recovery ratio is the extent to which loan amount is payable in full. Thus, complete loans recovery depends not only on the total of all individual cash repayments. Repayment default is broadly defined to include payment in arrears and repayment evasion (Okae-Adjel \& Samuel, 2012). An efficiently managed loans scheme will both maintain administrative costs at reasonably low levels and minimize the extent of repayment default.

The extent to which the recovery loan focuses more widely the scheme as a whole, rather than the student borrower which many factors contribute to it like, grace periods, administrative cost, repayment period and many others. Then, the researcher makes an assumption that, trending unemployment rates for graduates' students are the primary factor influencing the cohort default rate. Our primary hypothesis for this study is that; as a country or state, as unemployment rates increases, the cohort default rate has also experienced an increase. In other words, in a country or states that have experienced the largest changes in unemployment, I would expect to observe a faster increase in the cohort default rate. Our secondary hypotheses are that, if unemployment rates are a major indicator of economic conditions with average student loan debt, I will find that student loan cohort defaults rates have increased, average debt levels increases as well.

The conceptual framework developed for this study is based on an exploration of the relationship between people and the environment; specifically, students and institutions of higher education. This study was constructed by emulating the research of (Kypuros; Christopher Anthony, 2009). The groundwork laid by Steiner has guided this study to identify and analyze key variables such as age, gender, ethnicity, and residency when considering their predilection to default. 


\subsection{The Value of Student Loan in Ghana}

The Ghana Students Loan trust fund have been measured in different ways by various researchers, the current need-based assessment compiled by the Student Loan Trust Fund (SLTF) statistically lacks validity and reliability as it is based on self-reported data from students and therefore, if this wants to be achieved, it needs to be checked properly (Atuahene \& Owusu-Ansah, 2013), Students are not aware of the operations of the SLTF; there should be education and sensitization of the loan to prospective and first-year students when marketing the scheme, this would help them to know the quality of the scheme,(Okae-Adjel \& Samuel, 2012),(Woodhall, 2007) for example observed that arguments in favor of repayable loans are based on both efficiency and equity. The ("World Development Report 2018: Learning to Realize Education's Promise," 2017) outlined some success approaches in improving the efficiency and financial viability of existing student loan programs while broadening their coverage is a major challenge(OkaeAdjel \& Samuel, 2012). Notwithstanding, this productivity is accomplished through ones' nature of the credit set up. The Students Loan Trust Fund Act 2011(Act 820) establishing the fund requires borrowers of the fund to subscribe to a Student Loan Protection Scheme that indemnifies the borrower against payment of outstanding debt to the fund as a result of death or permanent disability. The loan protection covers the duration of the loan. $0.5 \%$ of the loan amount is deducted from loans granted to borrowers. Bad debts are provided for estimating $5 \%$ on loans due for repayment (i.e. mature loans) a lot of student organizations have mounted pressure on the board and the Ministry of Education. With an executive meeting as at 2015, the base sum has been expanded from GHc650 to a GHc1, 000 and the most extreme has been expanded from a GHc1, 600 to $\mathrm{GHc} 3,000$ " With the report, the board arrived at the decision after a number of considerations. "So, the average student will be getting a GHc1, 500, and it is also because many of the students fall into category three. At classification three, we are getting about GHc1, 800 or GHc1, 700 partitioned into two more than two scholastic years. Students in private institution also benefit from the SLTF; this was elaborated by The SLTF Executive Director. "Whether you are in private or public university, as long as it is a tertiary institution and accredited, the Ghanaian student will qualify for it. The student loan trust fund supported about 30,000 Ghanaians in 2015." (13th September 2016).

\subsection{Student Loan Application in Ghana}

Student application takes various forms in most countries. The loan application must be ensured by any of the supplementary financiers (SSNIT provider, Recognized Religious Body, Metropolitan, Municipal and District Assembly and Corporate body). To begin with, SSNIT commitment as indicated by the SLTF, one ought to or should be a Ghanaian, must be a dynamic supporter to the SSNIT benefits plot, more likely than not added to the SSNIT conspire for no less than 36 months or 3 years, must not be over 53 years of age and should not have ensured for more than one (1) individual as of now (be that as it may, guardians are given the chance to ensure for every one of their kids). This scheme strategies ought to be taken after as a provider of this before given the nod ahead to have admittance to the acclaim.

Secondly, religious bodies play a key role when it comes to application. One must be a member of a recognized, national religious body and must be an evidence of the institution's decision to guarantee. Thirdly, applications cannot be done without metropolitan, municipal and district assemble given you evidence of resolution by the assembly to guarantee with two (2) authorized resolutions including the chief executive own. Fourthly, corporate bodies must be an of Ghana club 100 or a company listed on the Ghana stock market at the time of guarantee with two the signatories should be at least at the senior management position. Ghana SLTF can apply online posted by SLTF and can also be communicated to the various campus offices designated by this body.

\subsection{Student Loan Disbursement by the SLTF in Ghana}

The process of student loan trust fund (SLTF) goes through a number of processes before the loan reaches the student borrower. A borrower collects a loan application document from the nearest SSNIT district office in which, newly admitted students are required to produce Admission Letters; while continuing students applying for the first time will be required to produce valid Student Identity Cards. Applicants are also required to produce valid Social Security Numbers before the Documents could be collected. Three guarantors would be required to endorse for the borrower and the guarantors should not be less than five years SSNIT contributor. The applicant then provides an active account for the money to be deposited in after two months of the process if, he or she meets the entire requirement. The student loan in Ghana disburses; 
Loans based on the means-tested and differentiated according to a program of study. From the SLTF, students offering science courses known as special courses gets a $10 \%$ higher amount of the loan than those in the humanities courses that are, social sciences and business courses. This is however on condition that; the loan application form has been properly completed and all relevant supporting documents attached to the application. The Operation

Department has established a fast-track loan processing machinery that ensures that students receive their loans in good time

\section{Analysis}

This section talks of how the researcher analyses the results based on data. According to this research, an average of the 2 percent estimate was given as an administrative cost for the other countries understudy apart from Ghana which has 3percent. This is the tabular representation of the various indicators from the study countries, which are; loan amount, interest rate, CPI, default ratio, Administrative cost, repayment ratio, and recovery ratio.

Among the countries, Tanzania has the highest loan amount of $\$ 1618$ which is over 6 times of Ghana's $\$ 260$. Rwanda follows with $\$ 1000$ which is over 3 times more than Ghana, then with Kenya and Nigeria the least on the table. Tanzania has $0 \%$ interest, had the second highest default rate. On the repayment of the student loan; Kenya has $71 \%$ as the highest with Rwanda, Tanzania, Nigeria, and Ghana follow respectively.

Table 4.1 Countries showing their loan amount, CPI, default rate, administrative cost, repayment, and recovery rate

\begin{tabular}{|c|c|c|c|c|c|c|c|}
\hline & & INTER & & & & & \\
\hline & LOAII & ENT & CPI & & AD & REPAIII & ReCOT \\
\hline COCYTR & ANOC & RIII & (\%) & DEFACL & COSI & $\mathrm{EN}$ & IRI \\
\hline I & $\mathrm{MT}(\$)$ & $(8)$ & & $\begin{array}{l}\text { I RITI } \\
\text { (b) }\end{array}$ & (bi) & $\begin{array}{l}\text { RHIIO } \\
(\%)\end{array}$ & $\begin{array}{l}\text { RIIIO } \\
\text { (10) }\end{array}$ \\
\hline GHAMA & 80 & 12 & 17 & 11.55 & 3 & 3271 & 128 \\
\hline BEVIA & 570 & 4 & 66 & 1235 & 2 & 412 & 596 \\
\hline $\begin{array}{l}\text { RTADA } \\
\text { TAZZANT }\end{array}$ & 1000 & 11 & 3 & 5588 & 2 & 6985 & 4.05 \\
\hline A & 1618 & 0 & 6 & 35.67 & 2 & 673 & 3.98 \\
\hline NGERHA & 159 & 12 & 9 & 12.80 & 2 & 5361 & 32.4 \\
\hline
\end{tabular}

Source: SLTF Ghana, HELB, Kenya, HESLS, Tanzania, REB, Rwanda, NSLB, Nigeria

With Ghana high-interest rate, it has the lowest repayment ratio of $32.71 \%$ which is the lowest among the five countries under study. With the recovery ratio, Rwanda has the highest with 44.05 whiles Tanzania is the second highest follow by Nigeria, Kenya, and Ghana. The default ratio of the various countries is balanced as you compared it with the recovery ratio. Rwanda has the highest default ratio with Nigeria placing second and Tanzania, Kenya, and Ghana following respectively. From the data above, Nigeria receives the lowest loan amount with an interest rate of $12 \%$ like Ghana but its repayment ratio, default ratio, and recovery is the 4 th, 4th, and 4th respectively among the five countries.

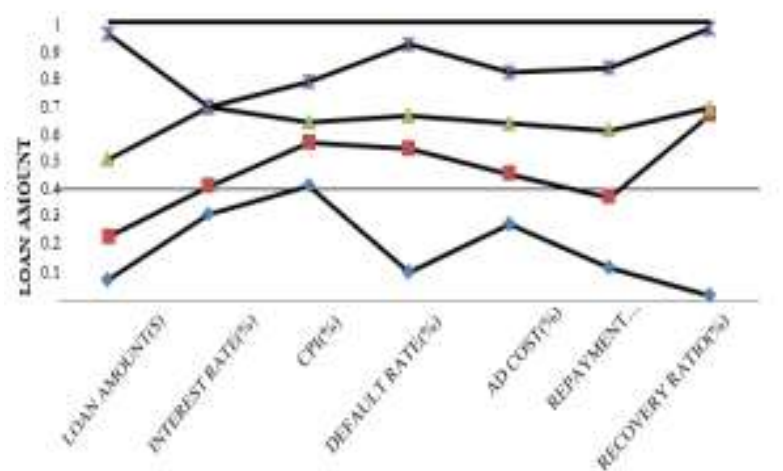

Figure 3: The diagram shows the statistical representation of all the country and the determinants for the measure.

Different colors are used to represent the various countries under study. From top to down per the graph, Nigeria, Tanzania, Rwanda, Kenya, and Ghana graphs are arranged from top to down. Loan amount for Tanzania is the highest but has no repayment interest all. The Rwanda student loans have the second highest amount deliver to its beneficiaries has in the fourth position when it comes to the default rate. With the repayment ratio and recovery rate, Nigeria has the highest but its loan amount is the lowest with the highest default rate. However, Ghana loan amount was the fourth among the countries under study placing third in default, last in repayment and $4^{\text {th }}$ in recovery rate. The Kenyan loan amount is the third highest in this study but was last in recovery and default rate. This does not suggest that there will not be any issue with the repayment. The graph shows that Tanzania has the third highest in default ratio, recovery and repayment ratio. With the fact that, there is no interest rate on their loan, students still default their loan policy, why?

Table 4.2 Repayment Ratio, Recovery Ratio, and Relative Efficiency Index (REI) 


\begin{tabular}{|c|c|c|c|}
\hline \multirow[t]{3}{*}{ COCNIR } & \multirow{3}{*}{ REPAIIIENT RATIO(\%) } & & RELATIVE \\
\hline & & RECOIERY & RATIEFFICIENCY \\
\hline & & (96) & NDEXYRED \\
\hline GHANA & 3657 & 13.57 & 2694915254 \\
\hline KENYA & 67.31 & 8.39 & 8.070321812 \\
\hline RWANDA & 68.45 & 37.37 & 1.831683168 \\
\hline TANZANA & & 20.76 & 3.241811175 \\
\hline NIGERIA & 5257 & 30.29 & 1.735556289 \\
\hline
\end{tabular}

Source: SLTF Ghana, HELB, Kenya, HESLS, Tanzania, REB, Rwanda, NSLB, Nigeria

The Relative Efficiency Index; this is emphasizing that a low recovery loans scheme does not necessarily mean an analytic of the inefficiency. The major element of the recovery ratio (required loan repayments) is fixed by government policy. Given the repayment ratio, inefficiency arises from sizeable default and high administrative costs (the other elements of the recovery ratio). Loan scheme inefficiency may be measured in terms of the relative difference between the repayment and recovery ratios. Hence, the researcher computes the Relative Efficiency Index (REI) as follows:

Relative Efficiency Index $=\quad 1 / 4$ Recovery Ratio/Repayment Ratio

Thus, the higher is the Relative Efficiency Index, the more efficient is the loans program. If the default was minimal and administrative costs restrained, then the difference between the Repayment Ratio and the Recovery Ratio would be small, resulting in a high Relative Efficiency Index (approaching unity). Results, for the schemes listed in Column of table 2 .

Five loans programs in (in Ghana, Kenya, Rwanda, Tanzania, and Nigeria) are relatively efficient. Kenya achieved the highest REIs of over 0.59 . The high REI of Kenya was due to loan amount covering tuition, academic user facilities, and accommodation and living expenses. However, Ghana had the second highest REI of 0.33 followed by Tanzania 0.29 , Nigeria 0.03 and Rwanda 0.02 . These four countries of REI below that of Kenya due to loan amount covers only living expenses not that of tuition and accommodation. Some countries like Ghana, Tanzania, Nigeria and Rwanda, the government provides subsidies to the tuition, accommodation and academic user facilities for state own institutions and therefore these amount is not included in the student loan amount given to the student. These countries in Africa show high resilient when it comes to student loan delivery and therefore there was no negative REI in the table.

It is useful to compare the two most efficient programs if it comes to the needs assessment of the student and Rwanda (category 2). The Kenya program emerges as the most efficient with an REI of 0.59 , followed closely by the Ghana program with an REI of 0.33 . Yet the Kenya repayment ratio $(71 \%)$ as also the highest with Ghana the lowest repayment ratio of $32.15 \%$ placing second as its recovery ratio $(0.59 \%$ for Kenya and $0.33 \%$ for Ghana). Since the administration cost defers in such cases as (2\% and 3\% respectively for Kenya and Ghana as an outstanding debt) and default rates are dissimilar $(11.25 \%$ and $51.12 \%$ respectively), the relative gap between recovery and repayment ratios in each scheme (as reflected in the REIs) is not the same. But the recovery ratios are much altered. This emphasizes the point that it is not the overall level of loans recovery (which is conditional on the loans repayment ratio, as designated by the government) that is important in measuring loans scheme efficiency. Rather, it is the relative effects of default and administrative costs in pulling down the recovery ratio and widening the gap between it and the repayment ratio.

From the report, the researcher thinks, this funding model would be a proper research in the future to pave a way for the development of the loan scheme and prevent loan scheme losses in Africa.

However, it is possible to provide a more general indication of the level of recovery ratios in Africa, relating specifically to the 5 schemes listed in Table 2 , even though administration costs are unknown for some of these schemes. The researcher did this by making conservative assumptions about the likely level of these costs in these 5 schemes, where it was difficult in getting information on the website and then simulating recovery ratios for each program. With the Ghanaian SLTF, the annual administrative cost was $3 \%$ and others 4 countries $2 \%$ assumed as an annual administration cost of outstanding loans debt each year; a similar assumption was made, and justification presented, in (Shen \& Ziderman, 2009) and (Salmi, 2001).

Table 2 shows all the 5 countries understudy recovery ratio. An average of $22.07 \%$ was recovered under a period of the study. This shows tremendous improvement in the repayment ratio of the current study, as compared to the study of (Shen \& Ziderman, 2009) with an

Average of $41.84 \%$ for eight African countries under study. In reality, recovery ratios are lower than those shown in Table 2.

Table 4.3 Showing the Recovery Ratio, 


\section{Repayment Ratio and Default Ratio Using Different Variables}

\begin{tabular}{|c|c|c|c|c|c|}
\hline VARLABLES & $\begin{array}{l}\text { OBERVA } \\
\text { TION }\end{array}$ & MEAN & $\begin{array}{l}\text { STANDARD } \\
\text { DEVIATION }\end{array}$ & IIN & MAX \\
\hline LOAYAMOCXT & 0 & 721.4 & 535.46 & 139 & 1618 \\
\hline CPI & 5 & 54 & 4.9 & 0 & 12 \\
\hline INIEREST RATE & 5 & 832 & 4.7 & 3 & 17 \\
\hline DEFALLTRATE & 5 & 3258 & 15.6 & 11.45 & 54.76 \\
\hline $\begin{array}{l}\text { ADSINISTRATIVE } \\
\text { COST }\end{array}$ & 5 & 3 & 0 & 3 & 3 \\
\hline REPAIYENT RATIO & 15 & 5852 & 12.5 & 3657 & 68.45 \\
\hline RECOVERY RHTIO & 5 & 22.076 & 10.6 & 8.39 & 37.37 \\
\hline
\end{tabular}

The figures of the mean, standard deviation, minimum, maximum all are in percentages. The table above shows the difference between the various variables, the mean default rate is $32.58 \%$ compared to the recovery ratio of $22.08 \%$. This shows that the default percentage is higher than the recovery ratio and this may not look healthy for the scheme to achieve $100 \%$ efficiency. Although repayment ratio is high mean, the value of loan amount is also high this suggests that there are gaps to be filled in terms of repayment. Loan repayment is also affected by the interest rate and the loan amount given as shown in the data.

\section{Conclusions}

The study was instituted to check the efficiency of the student loan repayment policy in Ghana compared to Kenya, Rwanda, Tanzania, and Nigeria. The Authorities of the SLTF highlighted that the best practice over the world is to survey the requirements of understudies and to build up financing gaps saving in mind the end goal to fill those holes (Okae-Adjel \& Samuel, 2012). They additionally showed that soon the SLTF will give out need-based loans and trusted this will give a sensible and considerable sum for people to finish their projects of study. This affirms the declaration of (Marcucci \& Johnstone, 2006) and (Ziderman \& Gan, 2005) that for cost sharing to work, it requires both need-based and implies strained loaners for replacements to obtain against their income (OkaeAdjel \& Samuel, 2012).

The discoveries of the analyst are as per the following: The productivity of the research acclaim method in elegant of repayment can't be accomplished in light of high financing cost of the research loan. Nevertheless, for countries with a low loan cost, its effectiveness is accomplished in light of the accessible employment after school. With a country like Tanzania with no financing cost for the research loan and a decent graduate pay, effectiveness of the reimbursement is being accomplished.

Relative efficiency index (REI) was utilized to quantify the different countries understudy. The outcomes anticipated that loan amount for countries like Ghana, Nigeria, Rwanda ought to be increment which covers just healthful and books remittance. With this expansion ought to akin with high graduate compensation which assists the research loaner with making accessible repayment after school. To concentrate on the outline, the loan amount given to Ghana, Kenya, Rwanda, Tanzania, and Nigeria compare by a boundary, Ghana and Nigeria are in the West and others in eastern Africa. With the review, the two West African nations are the most notable financing cost and the least loan amount given as compared to the East African countries.

In other to decrease the default rate of the study loans since its beginning, the receivers who default the procedure must pay the credit from their government debility finance and there must be an administrative instrument to back it. The speed and inadequate positioning and outlining of the scheme in the preparatory phase of its foundation put the SLTF, HESLB, REB, HESLS and NSLS in a selfconscious position without an observing basis. This has driven the scheme far from accomplishing its intentions.

Furthermore, for auspiciousness, SLTF in Ghana ought to liaise with the different foundations on its plan to incorporate a procedure whereby application into a tertiary establishment and that for the loan will be done all the time. Consequently, when a research is affirmed, the school to be an enlisted research, the loan handling and supply would start.

As a presaging in Africa, with this study, this experiences in studying the student loan can be used in Asia and other developing countries. The researcher will recommend distinctive realities acknowledges the recovery of the loan should access their normal code of ethics of the loan scheme.

\section{Reference}

[1] Agostino, M. (2008). World Bank Conditional Loans and Private Investment in Recipient Countries. World Development (Vol. 36). Elsevier Ltd.https://doi.org/10.1016/j.worlddev.2007. 
10.012

[2] Atuahene, F. (2008). Higher Education Finance in Ghana. International Higher Education, 50, 20-21.

[3] Atuahene, F., \& Owusu-Ansah, A. (2013). A descriptive assessment of higher education access, participation, equity, and disparity in Ghana. SAGE Open, 3(3), 1-16. https://doi.org/10.1177/2158244013497725

[4] Board, N. S. L. (2018). Nigeria Student Loans Board: How to apply for students and requirements. Nigeria. Retrieved from https://schoolings.org/nigerian-studentsloans-board-how-to-apply- for-students-loanand-requirements/

[5] Chapman, B., \& Lorraine, D. (2017). Conceptual and empirical Irlissues for alternative student Irlloan designs: the significance $|r|$ no loan repayment burdens Irlfor the US. Centre for Global Higher Education Working Paper Series, (17)

[6] Fatunde, T. (2013, June 1). First student loan scheme bill passes second reading. World University News. Retrieved from http://www.universityworldnews.com/article. php?story $=20130531170112939$

[7] Flint, T. a. (1997). Loan Defaults Predicting Student insured. The Journal of Higher Education, 68(3), 322-354.

[8] [8]Graphic.comgh. (2018).Student's loan increase put pressure on the fund. Accra. https://doi.org/648420

[9] Johnstone, D. B., \& Marcucci, P. N. (2007). Worldwide trends in higher education finance: Cost- sharing, student loans, and the support of academic research. UNESCO Forum on Higher Education, Research and Development, 1-36.

[10] Junor, S., \& Usher, A. (2008). Student Mobility \& Credit Transfer: A National and Global Survey. Educational Policy Institute, (June). Retrieved from http://ezproxy.lib.uconn.edu/login

[11] Kypuros; Christopher Anthony. (2009). Factors affecting student loan default rates: Nevada System of Higher Education Purdue University - West Lafayette. ProQuest Dissertations and Theses. Retrieved From http://purdue-primoprod.hosted.exlibrisgroup.com/primo

[12] Marcucci, P. N., \& Johnstone, D. B. (2006). International Higher Education Finance: An Annotated Bibliography. Publication Series Center for International Higher Education,
$1-180$.

[13] Mussa, A. (2015). Sustainability of Higher Education Students' Loan Scheme (HESLS) in Tanzania, 7(9), 149-164.

[14] Nyahende, V. R. (2017). Students' Loans by Financial Institutions: The way to reduce a burden for Government Funding to Higher Education in Tanzania, 16(11), 92-115.

[15] Okae-Adjel, \& Samuel. (2012). Student Loans as an Alternative to Funding Higher Education in Ghana: An Analysis of the Students Loan Trust Fund. Interdisciplinary Journal of Contemporary Research in Business, 4(6), 282-292.

[16] Pantah, A.-M. (2018). Higher Education Accessibility and Financial Sustainability in Ghana: The Role of the Student Loan Scheme. Introduction. Int. J. Adv. Res. Int. J. $A d v . \quad$ Res, 6(62), 2320-5407. https://doi.org/10.21474/IJAR01/6536

[17] Psacharopoulos, G., \& Patrinos, H. A. (2004). Returns to investment in education: A further update. Education Economics, 12(2),

111-134. https://doi.org/10.1080/09645290420002391 40

[18] Rossouw, G. J. (2008). Balancing corporate and social interests: Corporate governance theory and practice GJ (Deon) Rossouw. African Journal of Business Ethics, 3(1), 2838.

[19] Rwanda, R. R. and J. M. (2014, February 21). No escape for Rwandan student loan defaulters as banks to trace beneficiaries.TheEastAfrican. Retrieved from

http://www.theeastafrican.co.ke/rwanda/New s/Rwandan-student-loan-defaulters-may-runbut cannot-hide-/1433218-2216694 j4hrxp/index.html

[20] Salmi, J. (2001). Student Loans in an International Perspective: The World Bank Experience. International Higher Education, 22(winter), 10. https://doi.org/10.1007/9783-319-03029-6 Secretary, E., Students, N., \& Board, L. (1992). Student loans in Nigeria, 700(November 1991), 443-449.

[21] Shen, H., \& Ziderman, A. (2009). Student loans repayment and recovery: International comparisons. Higher Education, 57(3), 315333. https://doi.org/10.1007/s10734-0089146-0

[22] Simkovic, M. (2013). Risk-Based Student Loans. Washington and Lee Law Review, 
$70(1)$

11.Retrievedfromhttps://scholarlycommons.1 aw.wlu.edu/wlulr/vol70/iss1/8

[23] Woodhall, M. (2007). Funding Higher Education: The contribution of economic thinking to debate and policy development. Education Working Papers Series, (8), 59. https://doi.org/10.1017/CBO9781107415324 .004

[24] [World Development Report 2018: Learning to Realize Education's Promise. (2017). https://doi.org/10.1596/978-1-4648-1096-1

[25] Ziderman, A. (2013). Increasing access to higher education through student loans. CES ifo DICE, 2, 11-18.

[26] Ziderman, A., \& Gan, R. (2005). Increasing Accessibility to Higher Education: A Role for Student Loans? (August).

\section{Author Profile}

Benjamin Korankye received his B.S. and M.S. degrees in Management and public administration from university of education, Wineba-Ghana and university of electronic science and technology of China in 2013 and 2017, respectively. During 2013 to 2015 , he stay in Ghana education service working in the administration and also tutor Christ the king catholic senior high school. He has now an author of four papers and a $\mathrm{PhD}$ candidate for Jiangsu University in school of management science and engineering. 